\title{
Timing and time perception: A selective review and commentary on recent reviews
}

\author{
Richard A. Block ${ }^{1 *}$ and Simon Grondin ${ }^{2}$ \\ ${ }^{1}$ Department of Psychology, Montana State University, Bozeman, MT, USA \\ ${ }^{2}$ École de psychologie, Université Laval, Québec City, OC, Canada \\ ${ }^{*}$ Correspondence: block@montana.edu \\ Edited by: \\ Claire Zedelius, University of California, Santa Barbara, USA \\ Reviewed by: \\ Hedderik Van Rijn, University of Groningen, Netherlands
}

Keywords: time perception, attention, animals, humans, commentary

\section{A commentary on}

Perception and estimation of time

by Fraisse, P. (1984). Annu. Rev. Psychol. 35, 1-36. doi: 10.1146/annurev.ps.35.020184. 000245

Properties of the internal clock: first- and second-order principles of subjective time by Allman, M. J., Teki, S., Griffiths, T. D., and Meck, W. H. (2014). Annu. Rev. Psychol. 65, 743-771. doi: 10.1146/ annurev-psych-010213-115117

A clear example of the progress in the field of timing and time perception could be obtained by contrasting two articles published 30 years apart in the influential Annual Review of Psychology (ARP): one by Fraisse (1984), and one by Allman et al. (2014). The fact that there was one author 30 years ago, and a group of authors now, is a tangible sign of the contemporary way of approaching scientific research. In his review, Fraisse emphasized the distinction between time perception and time estimation; in their review, Allman et al. focused on the internal clock and the cerebral bases of timing and time perception.

Fraisse's review was published when a very important event happened in the field of timing and time perception: a conference was held in New York, in 1983, where researchers from both human and animal time perception met to communicate with one another. The conference led to the publication of the classical book edited by the late John Gibbon and the late Lorraine Allan (Gibbon and Allan, 1984). This meeting probably catalyzed the research on timing and time perception, especially the one emphasizing the scalar expectancy theory and, more generally speaking, the internal clock perspective, a clock described as a pacemaker-counter device.

It is somewhat surprising that there was no mention in Fraisse (1984) of this promising (to say the least) pacemakercounter perspective, which was already available in the human timing literature (Creelman, 1962; Treisman, 1963). Moreover, the modest portions of information in Fraisse dedicated to the cerebral bases of timing exemplify the gap between the contemporary research in the field and the state of the literature 30 years ago.

With its emphasis on neuroscience literature (e.g., brain areas, cortical circuits, pharmacological effects, and pathologies), Allman et al. wrote an important, wellstructured, and interesting state-of-the-art review on the cerebral bases of the time perception mechanisms. It is a bit surprising though that the scalar property is taken for granted, given actually Fraisse's fundamental distinction between time perception and time estimation, a distinction that could find some echoes in the limitation of the stability of the Weber fraction for time (see Figure 3 in Gibbon et al., 1997; or, for instance, Grondin, 2001, 2010b, 2012, 2015). Moreover, assuming the linearity between psychological and physical time (psychophysical law) remains disputable (Eisler, 1976).

By emphasizing the internal clock perspective, it was not possible for Allman et al. (2014) to refer to other recent developments in the field. Amongst the portions of the literature the reader might want to consider, there is one on retrospective timing (Block and Zakay, 1997; Tobin et al., 2010). There is also some interesting research (e.g., Boltz, 1998; Brown, 2008) offering a purely cognitive explanation of psychological time and timingwithout reference to an internal clock (see reviews by Block et al., 1999, 2010; Block, 2003). Even within the perspective of an internal clock, the attentional-gate model (see for example, Zakay and Block, 1995 and later articles), which in an extension of the scalar expectancy theory, is worth mentioning.

Indeed, with the large increase of research in the field of timing and time perception in the Twenty-first century, it is not surprising to see so many recent special issues of journals on this topic, or close variants of them. The explosion is such that researchers have written a large number of recent review articles (see Table $\mathbf{1}$ ). This was partly described in an annotated bibliography on "Time Perception" (Block and Hancock, 2013). Another tangible sign of the vitality of this research field is exemplified by a large COST grant funded by the E.U. (title: "Time In MEntaL activitY," or "TIMELY") and the resulting founding of the Brill's new scientific journal dedicated to the psychology of time, Timing and Time Perception, co-edited by Meck et al.

In conclusion, being a researcher in the field of timing and time perception has never been as exciting as it is at present, given the growth of its popularity, which has been enhanced by the arrival of contributions from neuroscientists. This 
Table 1 | Selected list (in reverse chronological order) of reviews since 2010 on the psychology of time.

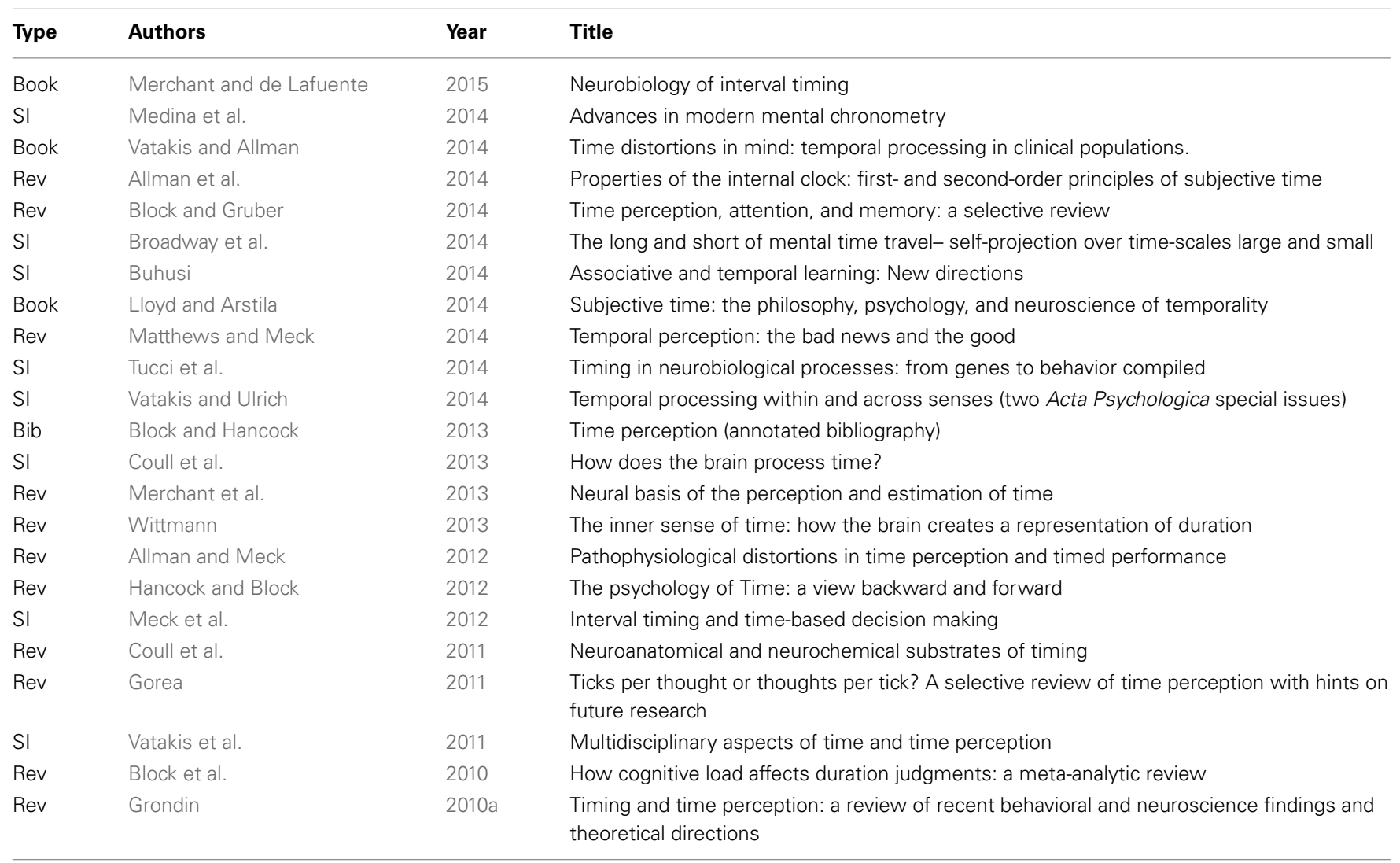

Book is an edited book. Rev is a review article. SI is a special issue. Bib is a bibliography.

excitement could be extended if one considers psychological time in an even larger perspective, or larger scale from the memory for the past events (Friedman, 1993) to the capacity to predict the duration of future events (Roy et al., 2005).

\section{ACKNOWLEDGMENT}

We thank Keith Hutchison and an anonymous reviewer for their very helpful suggestions on drafts of this commentary.

\section{REFERENCES}

Allman, M. J., and Meck, W. H. (2012). Pathophysiological distortions in time perception and timed performance. Brain 135, 656-677. doi: 10.1093/brain/awr210

Allman, M. J., Teki, S., Griffiths, T. D., and Meck, W. H. (2014). Properties of the internal clock: firstand second-order principles of subjective time. Annu. Rev. Psychol. 65, 743-771. doi: 10.1146/ annurev-psych-010213-115117

Block, R. A. (2003). "Psychological timing without a timer: the roles of attention and memory," in Time and Mind II, ed H. Helfrich (Cambridge, MA: Hogrefe \& Huber), 41-60.

Block, R. A., and Gruber, R. P. (2014). Time perception, attention, and memory: a selective review. Acta Psychol. 149, 129-133. doi: 10.1016/j.actpsy. 2013.11.003
Block, R. A., and Hancock, P. A. (2013). "Time perception," in Annotated Bibliography (Oxford Online Bibliographies), 284-295. http://www. oxfordbibliographies.com

Block, R. A., Hancock, P. A., and Zakay, D. (2010). How cognitive load affects duration judgments: a meta-analytic review. Acta Psychol. 134, 330-343. doi: 10.1016/j.actpsy.2010.03.006

Block, R. A., and Zakay, D. (1997). Prospective and retrospective duration judgments: a metaanalytic review. Psychon. Bull. Rev. 4, 184-197. doi: 10.3758/BF03209393

Block, R. A., Zakay, D., and Hancock, P. A. (1999). Developmental changes in human duration judgments: a meta-analytic review. Dev. Rev. 19, 183-211. doi: 10.1006/drev.1998. 0475

Boltz, M. G. (1998). The processing of temporal and nontemporal information in the remembering of event durations and musical structure. J. Exp. Psychol. Hum. Percept. Perform. 24, 1087-1104. doi: 10.1037/0096-1523.24.4.1087

Broadway, J. M., Zedelius, C., Schooler, J., and Grondin, S. (2014). The long and short of mental time travel- self-projection over time-scales large and small. Front. Psychol. Perception Science.

Brown, S. W. (2008). "Time and attention: review of the literature," in Psychology of Time, ed S. Grondin (Bingley: Emerald), 111-138.

Buhusi, C. V. (2014). Associative and temporal learning: new directions. Behav. Process. 101, 1-3. doi: 10.1016/j.beproc.2014.01.005
Coull, J. T., Cheng, R.-K., and Meck, W. H. (2011) Neuroanatomical and neurochemical substrates of timing. Neuropsychopharmacology 36, 3-25. doi: 10.1038/npp.2010.113

Coull, J. T., Van Wassenhove, V., and Coslett, H. B. (eds.). (2013). How does the brain process time? Neuropsychologia 51, 187-384.

Creelman, C. D. (1962). Human discrimination of auditory duration. J. Acoust. Soc. Am. 34, 582-593. doi: 10.1121/1.1918172

Eisler, H. (1976). Experiments on subjective duration 1878-1975: a collection of power function exponents. Psychol. Bull. 83, 185-200. doi: 10.1037/0033-2909.83.6.1154

Fraisse, P. (1984). Perception and estimation of time. Annu. Rev. Psychol. 35, 1-36. doi: 10.1146/annurev. ps.35.020184.000245

Friedman, W. J. (1993). Memory for the time of past events. Psychol. Bull. 113, 44-66. doi: 10.1037/0033-2909.113.1.44

Gibbon, J., and Allan, L. G. (eds.). (1984). Annals of the New York Academy of Sciences. Vol. 423. Timing and Time Perception. New York, NY: New York Academy of Sciences.

Gibbon, J., Malapani, C., Dale, C. L., and Gallistel, C. (1997). Toward a neurobiology of temporal cognition: advances and challenges. Curr. Opin. Neurobiol. 7, 170-184. doi: 10.1016/S09594388(97)80005-0

Gorea, A. (2011). Ticks per thought or thoughts per tick? A selective review of time perception with 
hints on future research. J. Physiol. 105, 153-163. doi: 10.1016/j.jphysparis.2011.09.008

Grondin, S. (2001). From physical time to the first and second moments of psychological time. Psychol. Bull. 127, 22-44. doi: 10.1037/0033-2909.127.1.22

Grondin, S. (2010a). Timing and time perception: a review of recent behavioral and neuroscience findings and theoretical directions. Atten. Percept. Psychophys. 72, 561-582. doi: 10.3758/APP.72. 3.561

Grondin, S. (2010b). Unequal Weber fraction for the categorization of brief temporal intervals. Atten. Percept. Psychophys. 72, 1422-1430. doi: 10.3758/APP.72.5.1422

Grondin, S. (2012). Violation of the scalar property for time perception between 1 and 2 seconds: evidence from interval discrimination, reproduction, and categorization. J. Exp. Psychol. Hum. Percept. Perform. 38, 880-890. doi: 10.1037/a0027188

Grondin, S. (2015). "About the (non)scalar property for time perception," in Neurobiology of Interval Timing, eds H. Merchant and V. de Lafuente (New York, NY: Springer).

Hancock, P. A., and Block, R. A. (2012). The psychology of time: A view backward and forward. Am. J. Psychol. 125, 267-274. doi: 10.5406/amerjpsyc. 125. 3.0267

Lloyd, D., and Arstila, V. (eds.). (2014). Subjective Time: The Philosophy, Psychology, and Neuroscience of Temporality. Cambridge, MA: MIT Press.

Matthews, W. J., and Meck, W. H. (2014). Time perception: the bad news and the good. WIREs Cogn. Sci. 5, 429-446. doi: 10.1002/wcs.1298

Meck, W. H., Doyère, V., and Gruart, A. (2012). Interval timing and time-based decision making. Front. Integr. Neurosci. 6:13. doi: 10.3389/fnint. 2012.00013
Medina, J. M., Wong, W., Díaz, J. A., and Colonius, H. (2014). Advances in modern mental chronometry. Front. Hum. Neurosci.

Merchant, H., and de Lafuente, V. (eds.). (2015). Neurobiology of Interval Timing. New York, NY: Springer.

Merchant, H., Harrington, D. L., and Meck, W. H. (2013). Neural basis of the perception and estimation of time. Annu. Rev. Neurosci. 36, 313-336. doi: 10.1146/annurev-neuro-062012-170349

Roy, M. M., Christenfeld, N. J. S., and McKenzie, C. R. M. (2005). Underestimation of future duration: memory incorrectly used or memory bias. Psychol. Bull. 131, 738-756. doi: 10.1037/00332909.131.5.738

Tobin, S., Bisson, N., and Grondin, S. (2010). An ecological approach to prospective and retrospective timing of long durations: a study involving gamers. PLoS ONE 5:e9271. doi: 10.1371/journal.pone.0009271

Treisman, M. (1963). Temporal discrimination and the indifference interval: implications for a model of the "internal clock." Psychol. Monogr. 77, 576. doi: 10.1037/h0093864

Tucci, V., Buhusi, C. V., Gallistel, R., and Meck, W. H. (2014). Timing in neurobiological processes: from genes to behaviour compiled. Philos. Trans. R. Soc. B 369:20120470. doi: 10.1098/rstb.2012.0470

Vatakis, A., and Allman, M. J. (eds.) (2014). Time Distortions in Mind: Temporal Processing in Clinical Populations. Boston, MA: Brill Academic Publishers.

Vatakis, A., Esposito, A., Giagkou, M., Cummins, F., and Papadelis, G. (2011). Multidisciplinary Aspects of Time and Time Perception. Vol. 6789. Lecture Notes in Computer Science, Berlin: Springer. doi: 10.1007/978-3-642-21478-3
Vatakis, A., and Ulrich, R. (eds.). (2014). Temporal processing within and across senses. Acta Psychol. (Amst.) 147(pt 1 and 2), 149. doi: 10.1016/j.actpsy.2014.01.001

Wittmann, M. (2013). The inner sense of time: how the brain creates a representation of duration. Nat. Rev. Neurosci. 14, 217-223. doi: 10.1038/ nrn3452

Zakay, D., and Block, R. A. (1995). "An attentionalgate model of prospective time estimation," in Time and the Dynamic Control of Behavior, eds M. Richelle, V. D. Keyser, G. d'Ydewalle, and A. Vandierendonck (Liège, Belgium: Université de Liège), 167-178.

Conflict of Interest Statement: The authors declare that the research was conducted in the absence of any commercial or financial relationships that could be construed as a potential conflict of interest.

Received: 02 May 2014; accepted: 06 June 2014; published online: 29 July 2014.

Citation: Block RA and Grondin S (2014) Timing and time perception: A selective review and commentary on recent reviews. Front. Psychol. 5:648. doi: 10.3389/fpsyg. 2014.00648

This article was submitted to Perception Science, a section of the journal Frontiers in Psychology.

Copyright $\odot 2014$ Block and Grondin. This is an openaccess article distributed under the terms of the Creative Commons Attribution License (CC BY). The use, distribution or reproduction in other forums is permitted, provided the original author(s) or licensor are credited and that the original publication in this journal is cited, in accordance with accepted academic practice. No use, distribution or reproduction is permitted which does not comply with these terms. 